\title{
中国のバャンオボ希土類一ニオブ一鉄鉱床
}

\author{
岸本文 男*

\section{On the Bayan Obo Rare-earth-Niobium-Iron Ore Deposits of China} \\ Fumio Kishimoto
}

\section{I.はじめに}

中華人民共和国内蒙古自治区の白雲鄂博（Báiyún-è-bó, 白雲博格都 Bái-yún-bó-gé-dū ともい う）に有名なバヤンオボ鉄鉱床があり（第 1 図）, その母岩は炭酸塩岩である。この鉱床は, その鉄 鉱石の希土類元素 $(\mathrm{RE})$ とニオブ $(\mathrm{Nb})$ の含有 率がとくに高いこと, そして母岩の $\mathrm{RE}$ と $\mathrm{Nb}$ の含有率も比較的高いこと, さらに鉱量 $(\mathrm{Fe}$, $\mathrm{RE}, \mathrm{Nb})$ が非常に多いことで最近世界的に注目 を集めるようになったものである。

現在, この鉱床の調査上開発に西ドイッが深く 関わっていると聞くが，西ドイッの地質・鉱床 · 採鉱などの専門家たちによる本鉱床についての論 文は見当らない。しかし, 1970年代に入って以降, 中国の地質専門家がとくにこの鉱床の生成タイプ の確定に向ってさまざまなアプローチを試み, 次 タに論文を発表している (巻末の “文献” 参照)。 これらの論文にもとづいて，筆者はバヤンオボ希 土類一ニオブー鉄鉱床の実体に関心をもっていた だこうと考えた。それがこの小論である。

\section{II. 鉱床調查研究史の概要}

本鉱床は，1927年 7 月 3 日, 当時の西北科学調 查団の調査行の過程で団員の一人, 丁道衡によっ て発見された。彼はのちに一文を発表して鉱床の 位置・地形・交通を明らかにし，1/3万の鉱床付 近の地質図をあらわし，付近の地質と地質構造， 鉱石の性質・品位を記載した（丁道衡 1933）。 彼の論文がバヤンオボ RE-Nb-鉄鉱床の記載の 最初のものである。しかし, 当時は $\mathrm{RE}$ と $\mathrm{Nb}$ の鉱床に関する知識が一般に乏しく, 鉱床全般の

* 地質調査所 Geological Survey of Japan
生成タイプに関する認識も現在ほど豊かではなか った。そのためであろうか，彼は本鉱床を高温熱 水性鉄鉱床と考えた。

その後, 1940年前後から日本の北支那開発株式 会社調查局が本鉱床を数次にわたって調查し，そ の調査にもとうく研究の結果は鉱床を珠質石灰岩 中の交代鉱床と結論づすものであった（菌部竜 - 1952)。

本鉱床の鉄鉱石が希土類鉱物を含んでいること を最初に記載したのは薗部竜一（1952）である が， RE だけでなく Nbにも富んでいることを最 初に発見したのはソ連の専門家たちである。それ は1954年に30名のソ連専門家が本鉱床の開発のた めに中国に迎えられて問もなくのことで，同時に 母岩が珪質石灰岩でなく，苦灰岩ということにな ってきた1)（李航英 1959）。そして李毓英(1959) によって鉱床の母岩は $\mathrm{RE}$ と $\mathrm{Nb}$ の含有率の高 い苦灰岩であることが指摘され，その苦灰岩は堆 積岩であり，鉄鉱物・ $\mathrm{RE}$ 鉱物・ $\mathrm{Nb}$ 鉱物のいず れも高温熱水作用の生成物とされた。その後，い わゆる「文化大革命」の時代の地質研究中断期を 経て, 本鉱床の調査研究が再開され，まず多成因 説（複合成因説）が登場した（王中剛・李紹柄・ 蘇賢沢 1973)。それによると，鉱石のタイプが 9 種あって, 水平・垂直両方向に鉱石のタイプ別 の累帯配列現象が認められ，それは堆積2) ・広域 変成・熱水交代の 3 種の鉱床生成作用の重複に原 因するものである。その翌年には，さらに詳細な モノグラフ (中国科学院地質研究所・貴陽地球化 学研究所 1974）が出版され, 王中剛・李紹柄ら と同様な見解が展開された。

そして，1980年に入って一つの新説が提起され た。それがカーボナタイト説である（周振玲・李 


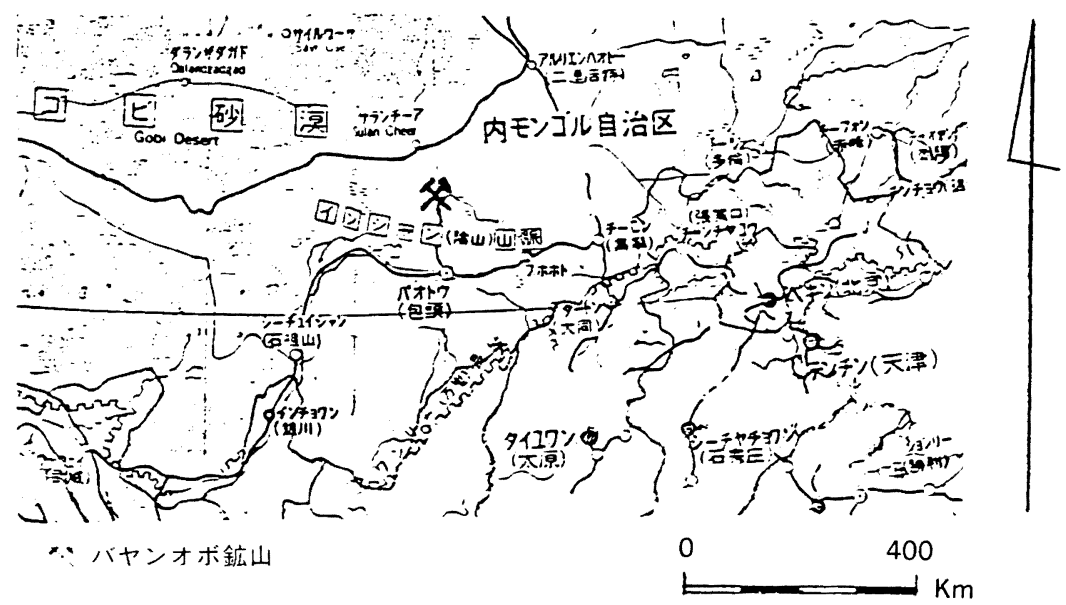

第1図 バヤンオボ鉱山位置図

功元ほか 1980)。この説によると, 本鉱床の炭 酸塩岩は苦灰石カーボナタイトであって, 堆積 岩ではなく, 鉱床はカーボナタイト鉱床であっ て, 高温熱水性鉱床でも堆積一変成一熱水交代鉱 床でもない。ところが，それからこんにちまでカ 一ボナタイト説を支持し, あるいは同説にたっ た論文がそれほど現われず3)，このバヤンオボ $\mathrm{RE}-\mathrm{Nb}$-鉄鉱床に関心を抱く研究者の数が増すな かで，スペリオル湖型鉄鉱床と生成環境が類似す る堆積鉱床に広域変成作用と酸性火成活動の影響 （熱水交代作用）が加わったとする論文（涂光裁 1981), 化石の発見や地球化学的な特徴および岩 石化学的な特街から当該炭酸塩岩を潟湖環境下で の堆積岩と結論つけた論文（孟慶潤 1982），鉱 床中の希土類元素の分配にみられる特徵から涂光 熾の見解を支持した論文（王凱怡 1981），鈗床 の胚胎層準と構造地質環境, 鉱石の構造とタイプ, 鉣石と母岩の同位体年代などから堆積一熱水交代 説を展開した論文（陳国達 1982），硫化物の $\delta$ $\mathrm{S}^{34}$ 值と炭酸塩の $\delta \mathrm{C}^{13}$ 值の特徴にもとういて当 該炭酸塩岩を堆積岩, 鉱床を堆積一変成一熱水生 成体とした論文（姜傳武・張任祐ほか 1982）, 本鉱床の東部鉱体部分から産出したセバアイトの 化学組成, 希土類元素組成, 結晶格子パラメータ, 赤外線吸収スペクトル, 結晶特性, 示差熱曲線に みられる特徴にもとづいて，鉱床の生成に熱水交
代作用が関与したと推論している論文（張培善・ 陶克捷 1983）が発表され，さらに，鉱石タイプ と当該鉱石産および母岩である炭酸塩岩産の磁鉄 鉱・赤鉄鉱の平均 $\delta \mathrm{O}^{18}$ 含有率との関倸にもとつい て本鉣床の堆積一変成一熱水交代説が説かれ（魏 菊英・上宮志冠 1983), あるいは鉱石と鉱石鉱物 （磁鉄鉱）および鉱床付近の岩石と主要造岩鉱物 の $\mathrm{Rb}^{87}, \mathrm{Sr}^{87} / \mathrm{Sr}^{86}, \delta \mathrm{O}^{18}, \delta \mathrm{C}^{13}$, 希土類含有率な どから本鉱床付近の炭酸塩岩には堆積岩とカーボ ナタイトの 2 種があり, 鉱床の生成は花崗岩と明 瞭な関係を有せず, カーボナタイトマグマによる という説明（白鸽・袁忠信 1983）が行なわれ, 中国の希土類一鉄鉱床の分類を試み，その分類で バャンオボ鉱床をバャンオボ型の代表例とし，こ れを堆積一接触変成一熱水交代鉱床と主張した研 究 (装愉卓·王中剠・趙振華 1981) もある。

\section{III. 位置・交通・地形}

位置および交通は第 1 図に示した通りである。 丁道衡による鉱床発見の1927年当時は綏遠（現在 のフホホト）から馬で 5 日間要したというが, 現 在は包頭から山元まで鉄道が通じ，交通は至便で ある。

包頭 (本鉱床の南方およそ $150 \mathrm{~km}$ )からモンゴル 人民共和国との国境（同じく北方およそ $80 \mathrm{~km}$ )に かけての地形は南側の陰山山脈と北側の内蒙古高 


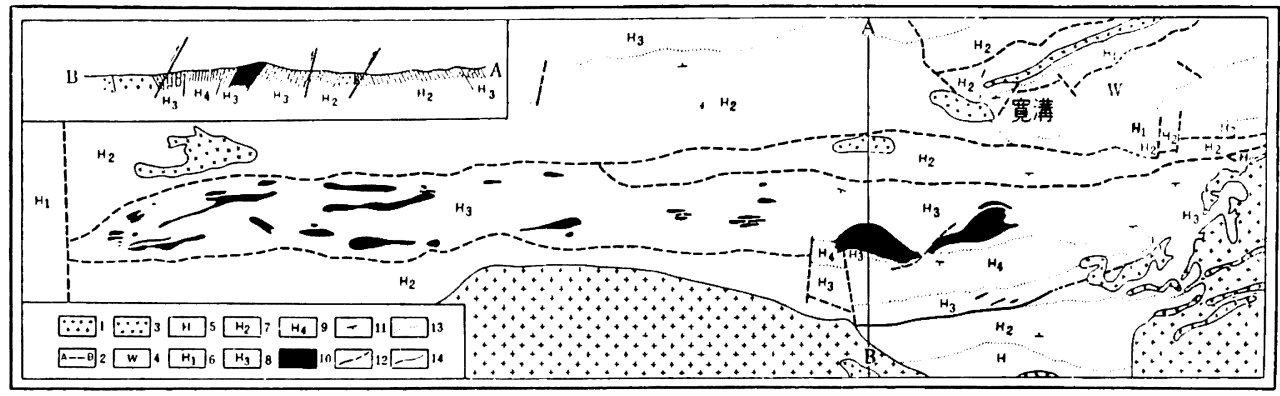

第 2 図 バヤンオボ鉣床区域の地質概要図（王中剛・李紹柄ほか 1973）

\begin{tabular}{|c|c|c|}
\hline 凡例：1一黒雲母花崗岩 & 2 一断面線 & $\begin{array}{l}3 \text { 一はんれい岩, はんれい閃緑岩 } \\
6 \text { 一珪岩, 砗岩 }\end{array}$ \\
\hline 4一始生界 & 5 ーミグマタイト化岩 & 6一珪岩, 碟岩 \\
\hline 7 一珪岩, 粘板岩 & $\begin{array}{c}8 \text { 一南側は珪岩・粘板 } \\
\text { として石灰岩 }\end{array}$ & 有する主として苦灰岩, 北 \\
\hline 9 一珪岩を挾有する粘板岩 & 10一鉄鉱体 & 11一走向, 傾斜 \\
\hline 12一確定および推定断層 & 13一地首境界線 & 14一貫入岩体境界線 \\
\hline
\end{tabular}

注：原図には方位も縮尺も入っていない。

原からなり, 前者は海抜がおおむね1,500-2,000m でほぼ東西に連なり, 後者はおよそ1,000-1,500m で北に向って緩やかに起伏しながら次第に低くな っている。白雲鄂博の町は陰山山脈の北麓にあっ て, 海抜は1,650m 前後, その北西の白雲鄂博山 の山頂（1主鉱体の大露頭部）は開発前には海抜 1,762m であったし，同山は今も一頭地を抜いた ドーム状の丘を形つくっている。

陰山山脈の北側では艾不改河（Ài-bù-găi 河） などが東北流ないし北流して，いずれも湖に注ぐ か, あるいは水無し川となり，南側では中小河川 が南西流ないし南流して黄河に合流する。とはい え, 両側とも河川は少なく, 水量も比較的乏しい。

陰山山脈の高峰部分には一つの侵食平面が発達 し, 山脈の北側斜面は比較的なだらかに, 比較的 スムースに内蒙古高原に移行するが, 南側斜面 は断層によって階段状に変化し, 河川上流の河床 は位置が高く，その部分は降雨直後だけ流水があ り，乾天が続けば水無し川になりやすい。それで も 3-4 m も掘れば，水を得ることができる。

\section{IV. 地 質}

本鉱床区域は卓状地と地向斜との中間帯に位置 し(王中剛・李紹柄ほか 1973), その卓状地は内 蒙古卓状地, 地向斜はヘルシニア優地向斜, その 中間帯は原生代劣地向斜であり(涂光傤 1981),
あるいは，本鉱床区域は天山一陰山東西性構造帯 の中央部, 白雲鄂博複背斜構造帯中に位置する (周振玲・李功元ほか 1980 , 孟慶潤 1982)。

鉱床付近は主として原生代の珪岩（メ夕石英砂 岩), 粘板岩, 礫岩, 炭酸塩岩からなり, 鉱床区域 の東から南にかけて黒雲母花崗岩が底盤状に広く 貫入・分布し，北と西にははんれい岩とはんれい 閃緑岩が岩株状および岩脈状を呈して上記の原生 界中に貫入すると同時に上記黒雲母花崗岩中にも 岩脈の形で貫入している。多くの研究者の説明は 上記の通りであるが，とくにアルカリ貫入岩類の 存在を強調する人々 (周振玲・李功元ほか 1980) やアルカリ粗面岩およびアルカリ流紋岩の活動を 認める人々（白鴿・㳖忠信 1983）もある。

鉱床を胚胎する炭酸塩岩については, 多くの研 究者が堆積岩と考え, カーボナタイト, すなわち マグマ岩とする研究者（周振玲・李功元ほか 19 80) も, 一部がカーボナタイト, 一部が堆積岩と する研究者(白鸽・袁忠信 1983)もみられる。こ の炭酸塩岩が南北 2 帯に分かれて分布することに ついては, 誰も異論を述べていない。しかし, 堆 積岩とする研究者の見解にも, 南側のものは苦灰 岩, 北側のものは主として石灰岩と珪質石灰岩, 一部が苦灰岩（孟慶潤 1982），いずれも主とし て苦灰岩（李航英 1959）などの異説がある。と はいえ, 鉱体周縁の炭酸塩岩がいずれも苦灰岩で 
第 1 表 李梳英（1959）の層序区分

\begin{tabular}{|c|c|c|c|}
\hline 層群 & 層 & 岩 & $\begin{array}{c}\text { 層厚 } \\
(\mathrm{m})\end{array}$ \\
\hline & $\mathrm{H}_{9}$ & 暗色粘板岩, 珪岩 & 234 \\
\hline & $\mathrm{H}_{8}$ & 苦灰岩, 希土類-Nb-鉄鉱体* & 520 \\
\hline バ & $\mathrm{H}_{7}$ & 珪質石灰岩, 珪岩 & 430 \\
\hline $\begin{array}{l}\text { t } \\
\text { ン }\end{array}$ & $\mathrm{H}_{6}$ & 淡色珪岩 & 310 \\
\hline オ & $\mathrm{H}_{5}$ & 暗色粘板岩 & 180 \\
\hline $\begin{array}{l}\text { ボ } \\
\text { 層 }\end{array}$ & $\mathrm{H}_{4}$ & 暗色珪岩 & 290 \\
\hline 群 & $\mathrm{H}_{3}$ & 暗色粘板岩 & 450 \\
\hline & $\mathrm{H}_{2}$ & 白色珪岩 & 280 \\
\hline & $\mathrm{H}_{1}$ & 暗色粘板岩, 粗粒珪岩 & 200 \\
\hline
\end{tabular}

あることは堆積岩説をとる研究者の誰むが認めて いるところである4)。

以上の岩石のほか, 鉱床区域の西一北西之南一 南西に第四系が分布し, 同系は砂・碟・泥層から なり, 西では鉱体群（炭酸塩岩体）を被覆し（周 振玲・李功元ほか 1980), あるいは炭酸塩岩体 と断層で接する（孟慶潤 1982）。

鉱床を胚胎する上述の炭酸塩岩を原生界の堆積 岩とみる研究者は, その層序を第 1 表や第 2 表の ように区分している。

このバヤンオボ層群（白雲鄂博層群）の地質時

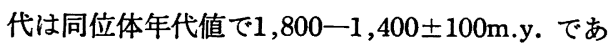
り, $\mathrm{H}_{8}$ の苦灰岩の場合は $1,500 \pm 100$ m.y. (肖仲

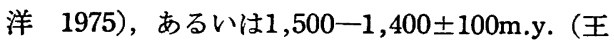
中剛・李紹柄ほか 1973）と測定され, 同層群は 原生代中期の堆積物と考えられている。一方，力 一ボナタイト論者は当該炭酸塩岩が苦灰石カーボ ナタイトで，その貫入は原生代マグマ活動の一環 としている。

前述の黒雲母花崗岩の底盤をはじめとする火成 岩類の貫入の時代については, それぞれの同位体 年代（たとえば，底盤をつくる粗粒黒雲母花崗岩 の黒雲母で $270 \pm 10$ m.y., 岩株を形うくく細粒黒 雲母花崗岩の黒雲母で $250 \pm 20 \mathrm{~m} . \mathrm{y}$.$) , 貫入一被貫$ 入の関係, 捕獲岩の岩相と産状および 捕獲一被 捕獾の関係, 接触一被接触変質現象, アルカリ成 分組成の特微などから一般にすべての火成岩類が 炭酸塩岩生成後の貫入岩, 主にバリスカン造山運 動末期の貫入岩と考えられているが，周振玲・李
功元ら (1980) はアルカリ岩類 (アルカリ閃長岩, アルカリ輝緑岩）の存在とその「カーボナタイ 卜」との同時代貫入を説いている。白鴿と袁忠信 (1983)がアルカリ粗面岩とアルカリ流紋岩の生成 を主張している根拠は東鉱体群の上盤などにカリ に富んだ(一般に $\left.\mathrm{K}_{2} \mathrm{O} \fallingdotseq 10 \%\right)$ 粘板岩があり，その 鉱物組成がこれら 2 種の岩石と酷似するというこ とであって, 当該岩体を確認しているわけではな い。また, 王凱怡・楊瑞英（1983）は岩石化学組 成, 希土類元素含有率と分布上の特徵から本鉱床 地域の東部と南東部に分布するはんれい岩体（バ ヤンオボはんれい岩）中にアルカリはんれい岩が 存在することを認めると同時に, バャンオボはん れい岩が底盤体花崗岩の生成前, 同時, 生成後の 3 期に分かれて形成されたとし, 本鉱床付近の火 成岩類の貫入が多期にわたったことを示唆してい る。

\section{V. 鉱 床}

本鉱床はバャンオボ山の山頂付近の主鉱体を最 大とする多数の可採鉱体群からなり，そのすべて が第 1 表および第 2 表中の $\mathrm{H}_{8}$ 層5)のうちの寛溝以 南に発達する部分に胚胎されている(第 2 図参照, 同図の記号 $\mathrm{H}_{3}$ の部分)。

鉱床を胚胎している $\mathrm{H}_{8}$ 層は主として苦灰岩で 構成されているが，そのほかに少量の粘板岩・珪 岩・苦灰石質珠岩などが挾有され（王中剛・李紹 柄ほか 1973)5)，もしくはそれらを捕獲し(周振 玲・李功元ほか 1980), あるいは石灰質雲母片 岩も挾有されている（孟慶潤 1982）。

鉱床は RE-Nb-鉄鉱体だけでなく，苦灰岩（周 振玲・李功元ら「1980」のいら苦灰石カーボナタ イト）自体が RE と $\mathrm{Nb}$ ないし $\mathrm{Nb}$ に富んだ鉱 体（第 3 表）からなり, 後者の場合は鉱体の輪郭 を画きわけることが難しい。RE-Nb-鉄鉱体の形 態については不規則塊状, 不規則レンズ状および レンズ状と表現できるが， RE-Nb 鉱体について は低品位のものまで含めれば， RE-Nb-鉄鉱体を 胚胎する苦灰岩体の苦灰岩全体が一大 RE-Nb 鉱 体といえるかもしれない。この苦灰岩体中の RE. $\mathrm{Nb}$ および $\mathrm{Nb}$ のとくに富鉱体の 形態と分布は まだ全体的には明らかにされていないが，現在稼 
等本文男

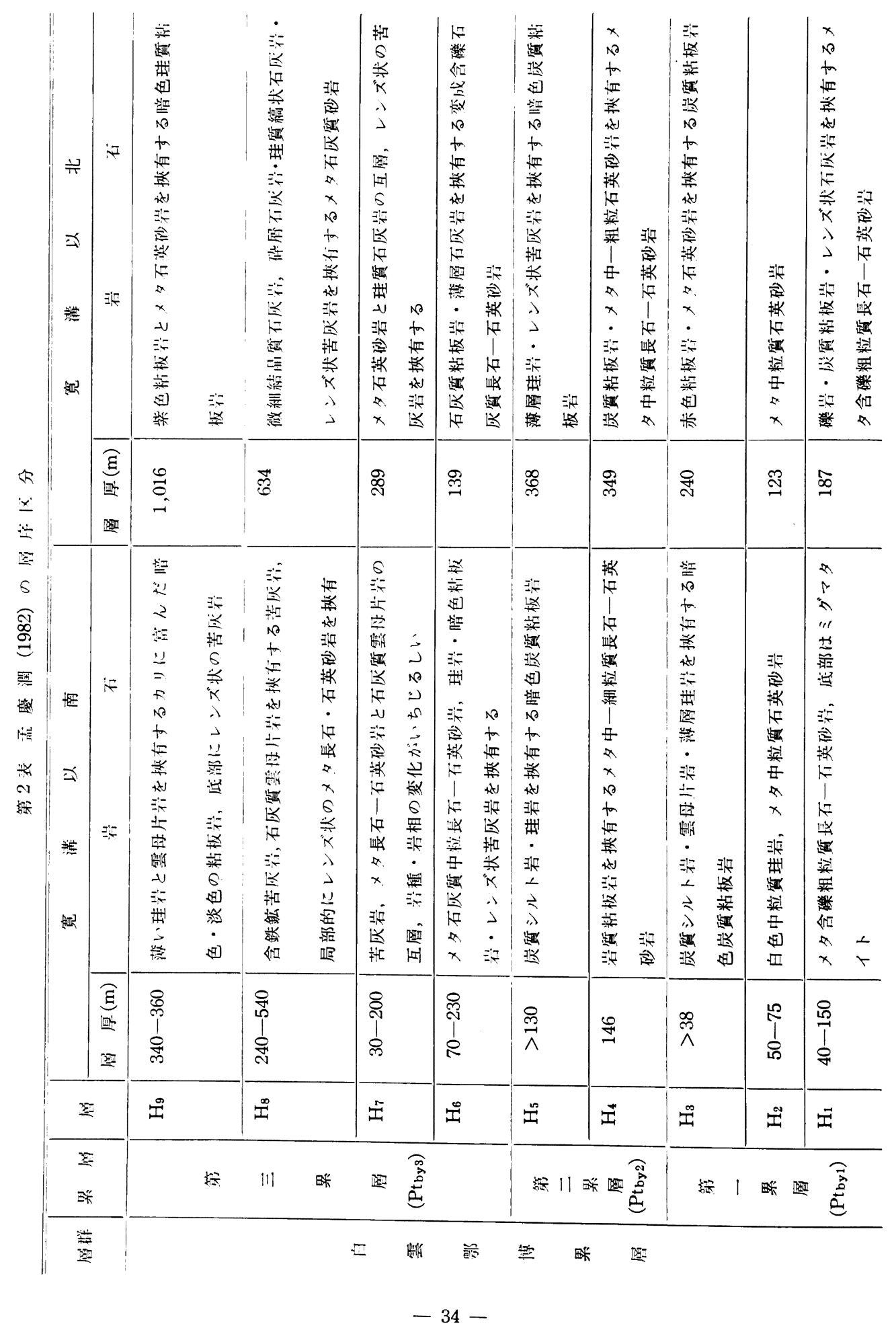




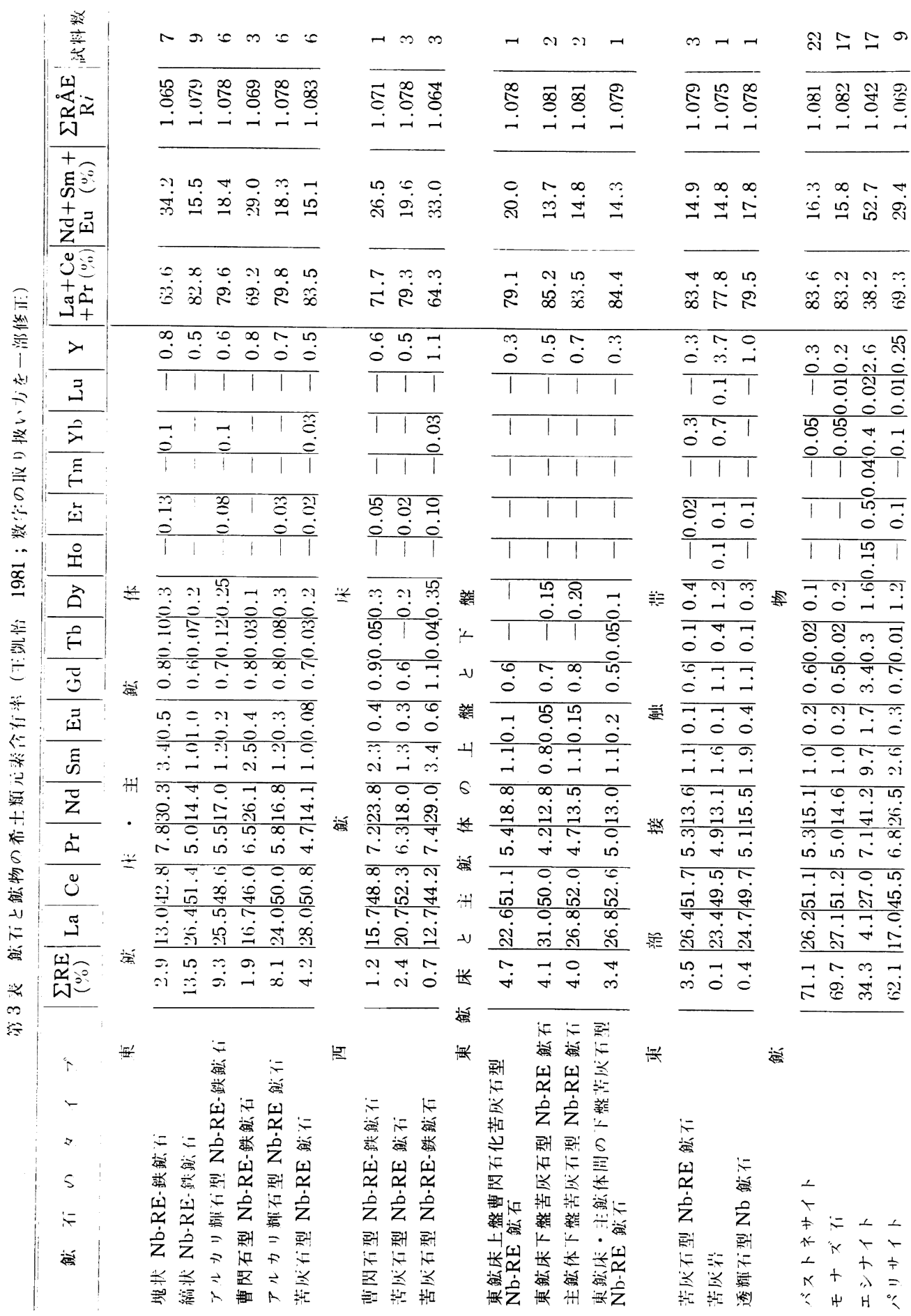




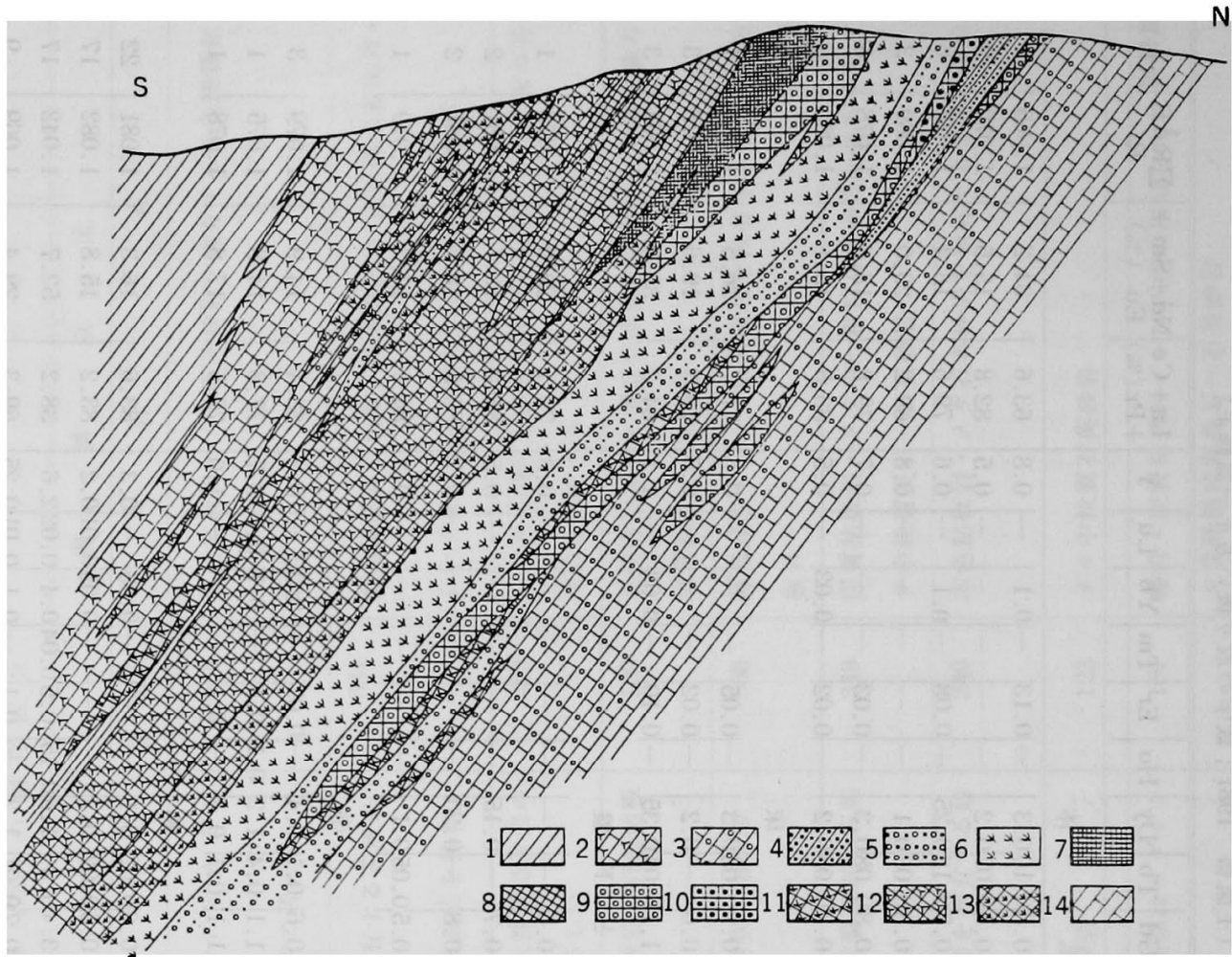

第 3 図 鉱体断面の模式図（王中剛・李紹柄ほか 1973）

凡 例：1一粘板岩, 黒雲母化粘板岩など 2-曹閃石化苦灰岩 3-含モナズ石苦灰岩 4 一珪岩 および緻密珪質岩 5一螢石珪岩 6-エジリン輝石岩, 螢石・エジリン輝石岩など 7 一塊 状磁鉄鉱鉣石 8 一塊状赤鉄鉣鉱石 9 一縞状螢石一赤鉄鉱鉱石および螢鉱一磁鉄石一赤鉄鉱鉱 石 10一石英-磁鉄鉱-赤鉄鉱鉱石 11一白雲母-磁鉄鉱鉱石 12-曹閃石一磁鉄鉱鉱石 13 -工 ジリン輝石・磁鉄鉣鈗石 14 一苦灰岩

行中のいわゆる主鉱体, すなわちバヤンオボ山山 頂付近の RE-Nb-鉄鉱体と RE-Nb 富鉱体につい ては王中剛・李紹柄ら (1973) によって記載され た断面図(第 3 図), 西鉱体区の場合については孟 慶潤 (1982，第 4 図)，陳国達（1982，第 5 図), 白鸽・袁忠信 (1983, 第 6 図) によってそれぞれ 記載あるいは紹介された断面図があり, また地質 平面図上に鉱床区域全域での鉱休の分布と各鉱体 （ただし RE-Nb- 鉄鉱体のみ）の形態を表わした ものとして王中剛・李紹柄ら(1973, 第 2 図), 周 振玲・李功元ら (1980, 第 7 図) などによる図が ある。

王中剛・李紹柄らは堆積変成一熱水交代成因説 にたつ人々であるが, 彼らの断面図および李航英
（1959）に発するバヤンオボ鉄鉱体群 の 分布図に よると, 当該 $\mathrm{RE}-\mathrm{Nb}$ 鉱体富鉣部の形態はレンズ 状ないし不規則レンズ状, 不規則塊状であるらし い。そうであれば， RE-Nb 鉱体も RE-Nb- 鉄鉱 体と形態的には同じようなものといえる。 鉱体の規模は主な鉄鉱体 (RE-Nb- 鉄鉱体) に ついてだけ記載されたことがある。まず丁道衡 （1933）は主鉱体を水平延長約 $500 \mathrm{~m}$, 平均の幅を 約 $600 \mathrm{~m}$, 平均の深さを約 $25 \mathrm{~m}$ (露頭部分) とみた のであるが, 稒部竜一（1952）は1940年の現地調 査の結果から主鉱体が隣接する 2 鉱体構成（東西 2 鉱体, 現在では西側のものが主鉱体, 東側のも のが 東鉱体とよばれている）で，その第 1 鉱体 (現在の主鉱体)の規模を東西水平延長 $900 \mathrm{~m}$, 幅最 
大 $300 \mathrm{~m}$ (平均 $200 \mathrm{~m}$ )，第 2 鉱体（現在の東 鉱体）の規模を東西水平延長 $700 \mathrm{~m}$, 幅最大 $150 \mathrm{~m}$ (平均 $100 \mathrm{~m}$ ), さらにその他の 鉄鉱体 (すなわち RE-Nb-鉄鉱体)の中で最大のもの が水平延長 $200 \mathrm{~m}$, 幅 $20 \mathrm{~m}$ 内外, そして小鉱体 の多くは水平延長が $10 \mathrm{~m}$ 内外, 幅が $2-3 \mathrm{~m}$ であると記載している。さらに白鵨・袁忠信 （1983）によると，主鉄鉱体と東鉄鉱体は紡錘 状を呈し，それぞれ延長は $1,000 \mathrm{~m}$ に近く， 厚さは300-400m に達し, 西鉱体群は16の小 鉄鉱体で構成されている。

鉱体とその側岩，たとえば主要 RE-Nb鉄鉱体とその側岩は第 3 図に示してあるよう に，下盤から上盤に大まかには，苦灰岩 $\rightarrow$ 縞 状螢石一赤鉄鉱 (十磁鉄鈗) 鉱石一螢石一珪 岩 $\longrightarrow$ エジリン輝石岩一縞状螢石一赤鉄鉱 (+ 磁鉄鉣）鉱石一塊状磁鉄鉱鉱石（上部）＋エジリ ン輝石一磁鉄鉣鉱石（下部）－塊状赤鉄鈗鉱石一 曹閃石一磁鉄鉱鉱石一エジリン輝石一磁鉄鉱鉱石 $\rightarrow$ 白雲母一磁鉄鉱鉱石 $\rightarrow$ 曹閃石化苦灰岩 $\rightarrow$ 粘板岩 という配列を形づくっている（王中剛・李紹柄ほ か 1973)

\section{VI. 鉱石と鉱石鉸物}

鉱石はその構造によって, 縞状鉱, 塊状鉱, 鉱

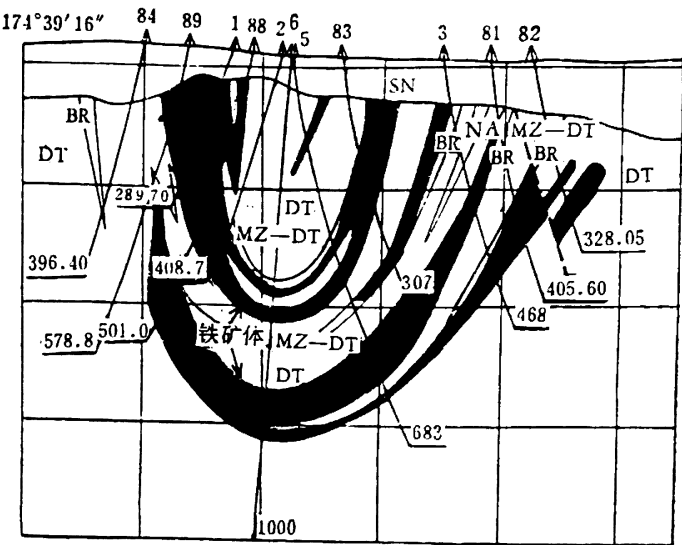

第 4 図 バヤンオポ鉄釷床西鉱体群断面30線の断面 図（孟慶潤 1982）

凡 例: $\mathrm{SN}$ 一表土 $\mathrm{DT}$ 一苦灰岩 $\mathrm{BR}$ 一雲母岩 NA一曹閃石岩 MT-DT一鉱化苦灰岩

染状鉱, 層状鉱に（装愉卓ほか 1981），あるいは 主要鉱石鉱物と主要脈石鉱物および鉱石構造によ って, 塊状磁鉄釷鉱石, 塊状赤鉄鉱鉱石, 縞状螢石 一赤鉄釷鉱石, 縞状螢石一磁鉄鉱一赤鉄釷鉣石, 石 英一磁鉄鉱一赤鉄鉱鉱石, 白雲母一磁鉄鉱鉱石, 曹 閃石一磁鉄鉱鉱石, エジリン輝石一磁鉄鉱鉱石, 含 モナズ石苦灰岩に(王中剛・李紹柄ほか 1973)， さらに主要な有用成分を加味して, 塊状 Nb-RE鉄 鉱, 縞状 Nb-RE- 鉄鉱, アルカリ輝石型 Nb-RE-

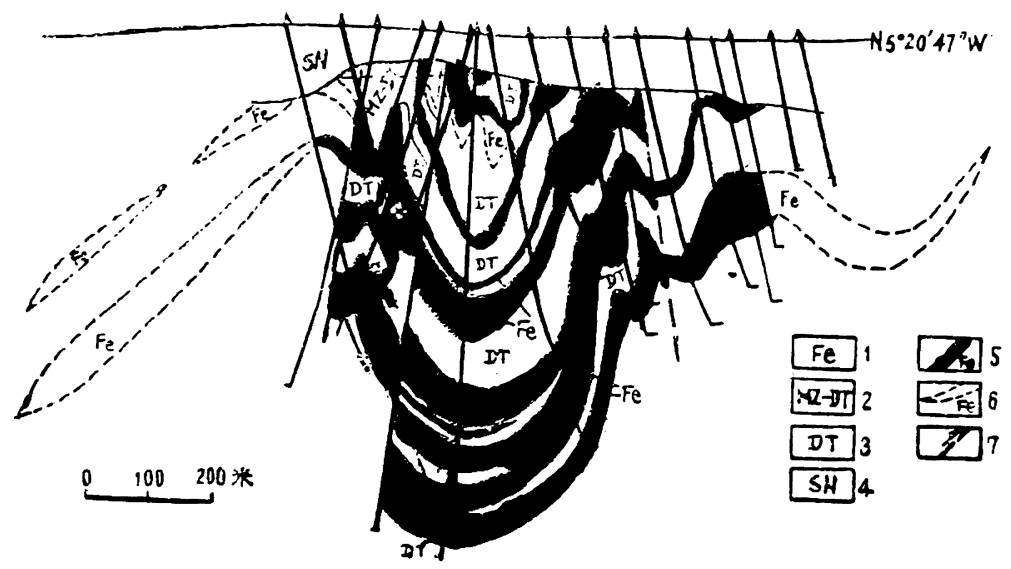

第 5 図 バャンオボ鉄鉱床第30号断面地質・物理探查総合図（陳国達 1982）
凡 例 : 1 -鉄鉱
2 一鉣化苦灰岩
3 一苦灰岩
4 一被覆層
5 一試錐探査による確定鉱体
6 一物理探査による推定鉱体
7 一推定断層 


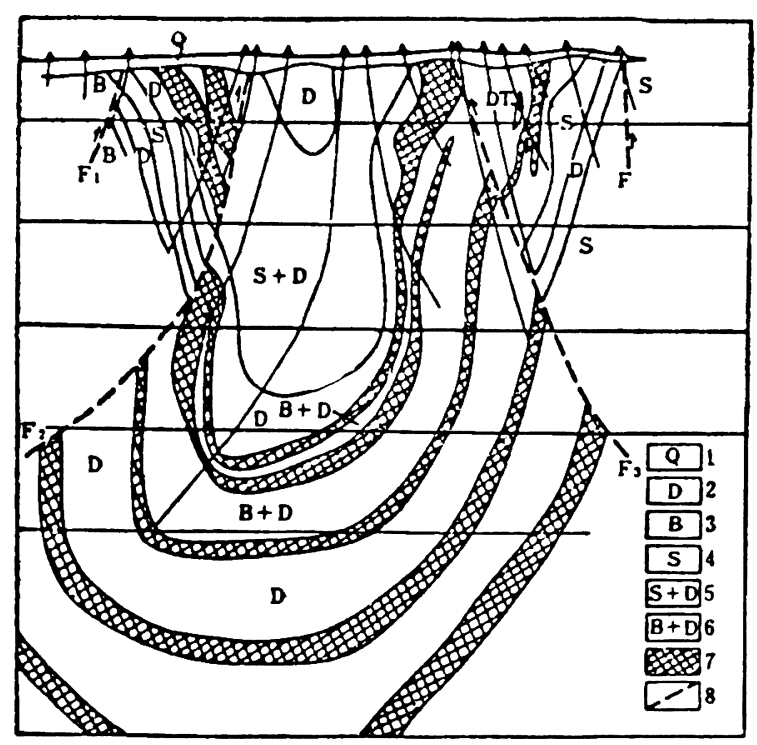

第 6 図 バヤンオボ鉱床西鉱体区の断面図（白鴿・袁忠信，1983）

凡 例：1一第四系 2 一苦灰岩型鉱石 3-黒雲母型鈗石 4 一粘板岩型鉱石 5 - 苦灰岩挾有粘板岩型鉱石 6 一苦灰岩挾有黒雲母型鉱石 7 一鉄鉱石 8 一断層

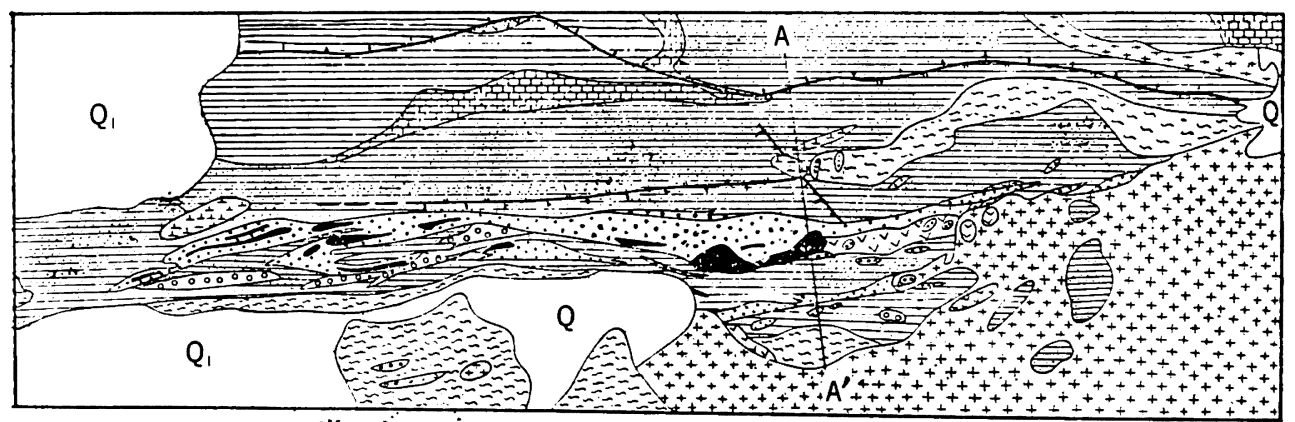

A

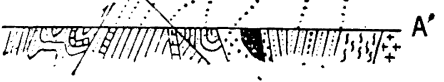

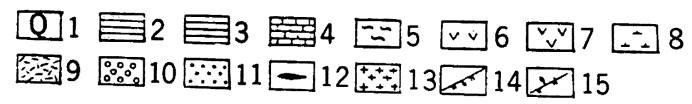

第 7 図 バャンオボ鉱床区域の地質概要図（周振玲・李功元ほか 1980）

凡例：1一第四系 2 一メ夕砂岩, 珪岩, 薄層石灰岩 3 一メ夕砂岩挾有粘板岩 4 一石灰岩 5 一ミグマタイト 6一超塩基性岩 7一はんれい岩, アルカリ輝緑岩 8一閃緑岩 9 一アルカリ閃長岩 10一中・粗粒質苦灰石カーボナタイト 11一細粒苦灰石カーボナ タイト 12一鉄鉱 13一花崗岩 14一正断層 15一逆断層

鉄鉱, 曹閃石型 Nb-RE- 鉄鉱, 苦灰石型 Nb-RE鉄鉱, アルカリ輝石型 Nb-RE 鉱, 苦灰石型 Nb$\mathrm{RE}$ 鉱, 曹閃石型 $\mathrm{Nb}-\mathrm{RE}$ 鉱に（表愉卓ほか 19 81）分類されている。そのほか，本鉱床の鉱石を
希土類を規準に, $\mathrm{RE}$-鉄鉱, 苦灰石型 $\mathrm{RE}$ 鉱, 珪 酸岩型 $\mathrm{RE}$ 鉱, 貫入カーボナタイト型 $\mathrm{RE}$ 鉱に 4 大別し、これをさらに19亜タイプに細分した報 告もある（白鴿・袁忠信 1983）が，その各タイ 


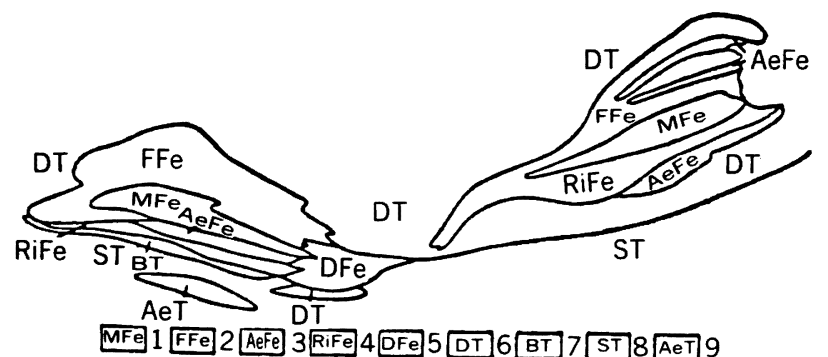

第 8 図バヤンオボ鉱床主鉱体および東鉱体付近の鉱石のタイプ別配列図（白䳌・袁忠信 1983）

凡 例 : 1一塊状 RE- 鉄鉱石

3 -エジリン輝石型 RE- 鉄鉱石

5 一苦灰石型 RE- 鉄鉱石

7 一黒雲母型 RE 鉣石

9 一エジリン偻石型 $\mathrm{RE}$ 鉣石
2 - 螢石型RE- 鉄鉣石

4 一曹閃石型 RE- 鉄鉱石

6 一苦灰石型 $\mathrm{RE}$ 鉱石

8 一高力リ粘板岩型 $\mathrm{RE}$ 鉣石
プ, 各亜タイプの特徴についての詳しい記載は見 当らない。白鴿と袁忠信（1983）によれば，最大 の鉱体（本鉱床東部の隣り合った 2 鉱体で, 一般 にそのうちの西側のものを主鉄鉱体，東側のもの を東鉄鉱体とよんでいる）での亜タイプ別の鉱石 の配列には規則性があり，いずれの場合も下部か ら上部に，縞状螢石型 RE-鉄鉱（赤鉄鉱）－塊状 $\mathrm{RE}$-鉄鉱 $\rightarrow$ エジリン輝石型 $\mathrm{RE}$-鉄鉱 $\rightarrow$ 曹閃石型 RE- 鉄鉱 $\rightarrow$ 苦灰石型 RE- 鉄鉣 $\rightarrow$ 黒雲母型 $\mathrm{RE}$ 鉣という配列を示す（第 8 図）。

スカルンの存在については, 戦時中すでに門倉 三能（1940）が「石灰岩」と鉄鉱体との接触部, とくに今でいう主鉄鉱体の西側の「石灰岩」と当 該主鉄鉱体との接触部に緑策石発達帯があって, ざくろ石などを伴なうことを記载し，最近では王 中㴊・李紹柄ら（1973）が本鉱床区域東部の花崗 岩類と苦灰岩との接触帯にマグネシアスカルンと $\mathrm{Nb}-\mathrm{RE}$-鉄鉱石が存在し, 幅 0.1-10 数m の透輝 石・金雲母・ヒューマイト・磁鉄鉣・螢石などか らなる鉱石を形うくくり，その中に希土類鉱物も含 まれていると報告している。このスカルンを主な 対象とした研究報告はでていないようであるが, スカルンの存在を否定する研究者はいない。 主な鉱石鉱物は, 磁鉄鉱と赤鉄鉱のほか, 希土 類鉣物とニオブ鉱物からなっている。周振玲・李 功元ら（1980）によると, 希土類の弗素炭酸塩鉱 物としてバストネサイト，パリサイト，七バアイ ト(cebaite), フアンホアイト (huanheite), コー ジライト(cordylite), 同じく珪酸塩鉱物として褐 策石，チェヴキナイト (chevkinite)，珪酸燐灰 セリウム鉣(原名：燐珪䤮鈰鉣), 同じくチタン・ タンタル・ニオブ酸塩鉱物としてエシナイト, ニオボエシナイト, チタノエシナイト, シニサイ 卜 (sinicite), 褐ニオブ酸セリウム鉱（原名: 褐 鈰鈮鉱)，同じく燐酸塩鉱物としてモナズ石が産 出し, これら希土類鉱物の含有率は周振玲・李功 元らのいうカーボナタイト中で $1-10 \%$ に達して いるが，その分布はきわめて不均等である。その 中でバストネサイトとモナズ石は分布範囲が広 く, 含有率も高い(パリサイトとファンホアイト がそれに次ぐ)。そしてバストネサイト(粒径0.05 $-0.5 \mathrm{~mm})$ の多くはモ十ズ石・磁鉄鉱・赤鉄鉣・ 螢石・燐灰石と共生する。またモナズ石（一般に 粒径が0.05-0.1 mm） は苦灰石の粒間に賦存し, 局部的にはバストネサイトなどとともに縞をつく っていることもある。このモナズ石の希土類元素 含有比は, La $30.48, \operatorname{Ce} 51.03, \operatorname{Pr} 4.61, \mathrm{Nb}$ 12.17, Sm 0.83, Eu 0.26, Gd 0.46, Dy 0.06 である。

ニオブ鉱物については周振玲・李功元ら(1980) も詳しく触れてはいない。本文末の文献のいずれ も, ニオブ鈗物を記載し，あるいはリストを掲げ るということをやっていない。ただ陳国達(1982) がバヤンオボ鉱床のニオブ鉱物としてコロンバイ 
ト、イルメノルチール，エシナイトなど12種と記 して，劉椡のタイプ印刷出版物 “白雲鄂博鉄砿” （1979）に詳しいと紹介し，白鸽と袁忠信（1983） がコロンバイト・ニオボルチール・パイロクロア ・エシナイトなどと記述しているだけである。 したがって当面, ニオブ鉱物の内容は劉椡の “白 雲鄂博鉄硪”に待つしかないようである。

なお，1980年に本鉱床区域の弱変成苦灰岩から 発見された希土類鉱物の新鉱物 として中華鈰鉱 $\mathrm{Ba}_{2} \mathrm{Ce}\left(\mathrm{CO}_{3}\right)_{3} \mathrm{~F}$ (zhonghuacerite) が張培善・陶 克捷（1981）によって記載されている。これは苦 灰岩を交代して鉱染した, 三方晶系に属する熱水 成の鉱物である。

本鉱床の主な脈石鉣物は, 苦灰石, アンケライ 卜, 方解石, 燐灰石, 螢石, 曹閃石, エジリン輝石,
重晶石などである。ただし，燐灰石を脈石鉱物と 言いきるには少し問題がある。本鉱床と周辺の炭 酸塩岩中の燐灰石は化学組成からすると， 3 種の ものがあり（周振玲・李功元ほか 1980), その $\mathrm{RE}_{2} \mathrm{O}_{3}$ の含有率はかなり高い。すなわち，弗素燐 灰石は $\mathrm{RE}_{2} \mathrm{O}_{3}$ を0.48-4.36\%， バリウム一希土 類燐灰石は同じく $\mathrm{RE}_{2} \mathrm{O}_{3}$ を $5 \%$ ないしそれ以上 (ほかに $\mathrm{BaO}>5 \%$ )，希土類燐灰石は $\mathrm{RE}_{2} \mathrm{O}_{3}$ を5.99-9.68\%それぞれ含んでいるのである。こ の燐灰石が濃集している部分（含有率 $=20 \% ） も$ あるので，あるいはすでに有効利用されているか も知れない。

\section{VII. 品位と鎕量}

本鉱床の有用成分の品位についてはさまざまな

第 4 表 白雲罰博鉱床カーボナタイト*の化学組成**

（周振玲・李功元ほか 1980）

\begin{tabular}{|c|c|c|c|c|c|}
\hline 試 料 & \multicolumn{2}{|c|}{ 前期カーボナタイト } & \multicolumn{2}{|c|}{ 後期カーボナタイト } & \multirow{2}{*}{ 平 $(\%)$ 均 } \\
\hline 成 分 & $\begin{array}{l}\text { 中-粗粒質苦灰石カー } \\
\text { ボナタイト(4 個) }(\%)\end{array}$ & $\begin{array}{c}\text { 平 均 } \\
(\%)\end{array}$ & $\begin{array}{l}\text { 細粒質苦灰石カーボ } \\
\text { ナタイ ト (4 個) }(\%)\end{array}$ & $\begin{array}{c}\text { 平 均 } \\
(\%)\end{array}$ & \\
\hline $\mathrm{SiO}_{2}$ & $0.29-2.71$ & 0.33 & $0.36-0.41$ & 0.39 & 0.47 \\
\hline $\mathrm{Al}_{2} \mathrm{O}_{3}$ & $0.01-0.07$ & 0.04 & $0.02-0.20$ & 0.08 & 0.05 \\
\hline $\mathrm{Fe}_{2} \mathrm{O}_{3}+\mathrm{FeO}$ & $3.04-6.43$ & 4.72 & $7.41-14.66$ & 11.19 & 7.95 \\
\hline $\mathrm{TiO}_{2}$ & $0.01-0.06$ & $0.02^{5}$ & $0.04-0.30$ & 0.12 & 0.07 \\
\hline $\mathrm{CaO}$ & $30.34-31.75$ & 31.34 & $26.09-28.44$ & 27.17 & 29.25 \\
\hline $\mathrm{MgO}$ & $15.51-17.26$ & 16.58 & $12.98-17.18$ & 14.16 & 15.37 \\
\hline $\mathrm{MnO}$ & $0.44-0.62$ & 0.56 & $0.37-1.74$ & 1.07 & 0.82 \\
\hline $\mathrm{K}_{2} \mathrm{O}$ & $0.05-0.11$ & 0.07 & $0.11-0.20$ & 0.13 & 0.10 \\
\hline $\mathrm{Na}_{2} \mathrm{O}$ & $0.11-0.16$ & 0.12 & $0.14-0.24$ & 0.18 & 0.15 \\
\hline $\mathrm{P}_{2} \mathrm{O}_{5}$ & $0.23-3.13$ & 1.64 & $0.26-0.52$ & 0.39 & 1.05 \\
\hline $\mathrm{RE}_{2} \mathrm{O}_{3}$ & $0.06-0.26$ & 0.14 & $1.82-3.94$ & 2.41 & 1.31 \\
\hline $\mathrm{Nb}_{2} \mathrm{O}_{5}$ & $0.37-0.13$ & 0.07 & $0.02-0.20$ & 0.08 & $0.07^{5}$ \\
\hline $\mathrm{Ta}_{2} \mathrm{O}_{5}$ & 痕跡一 $0.003^{5}$ & $0.001^{5}$ & 痕跡一 $-0.004^{5}$ & $0.002^{5}$ & 0.002 \\
\hline $\mathrm{F}$ & $0.06-0.24$ & $0.14^{5}$ & $0.12-2.02$ & 1.10 & $0.62^{5}$ \\
\hline $\mathrm{H}_{2} \mathrm{O}$ & $0.24-0.60$ & 0.46 & $0.21-0.92$ & 0.67 & 0.57 \\
\hline $\mathrm{CO}_{2}$ & $38.48-42.55$ & 40.51 & $35.40-38.94$ & 37.29 & 38.9 \\
\hline 灼 熱 減 量 & $41.55-43.59$ & 42.47 & $36.47-42.51$ & 38.79 & 40.63 \\
\hline
\end{tabular}

* 篗者注：周振玲，李功元らはカーボナタイト説をたてている。

** 筆者注：数值の取扱い，とくに桁のとり方が原文では誤っているので，それを修正した。 ミスプリントと思われる所もあるが，修正しようもないので，それは原文通りにした。 ただ $\mathrm{Al}_{2} \mathrm{O}_{3}$ の最左端の数值は原文では 0.61 となっている。また $\mathrm{SiO}_{2}$ の左欗の 0.33 は $0.83, \mathrm{Nb}_{2} \mathrm{O}_{5}$ の最左端の 0.37 は 0.03 ではないかと思われる。 
第 5 表 白雲郘博鉱床の鉱石およびそれに関係ある岩石の希土類元素含有量 (ppm)

（㛏愉卓・王中剛ほか 1981）

\begin{tabular}{|c|c|c|c|c|c|c|c|}
\hline & $\begin{array}{l}\text { 塊状 Nb-RE- } \\
\text { 鉄鉱石 }\end{array}$ & $\begin{array}{r}\text { 縞状 Nb- } \\
\mathrm{RE}-\text { 鉄鉱石 }\end{array}$ & $\mid \begin{array}{l}\text { Yーダ輝石 } \\
\text { 型 Nb-RE- } \\
\text { 鉄鉱石 }\end{array}$ & $\begin{array}{l}\text { 曹閃石型 Nb- } \\
\mathrm{RE} \text {-鉄鉣石 }\end{array}$ & $\begin{array}{l}\text { 苦灰石型 } \mathrm{Nb}- \\
\mathrm{RE}-\text { 鉄鉱石 }\end{array}$ & $\begin{array}{l}\text { ソーダ輝石型 } \\
\mathrm{Nb}-\mathrm{RE} \text { 鉣石 }\end{array}$ & $\begin{array}{l}\text { 苦灰石型 Nb- } \\
\text { RE-釷石 }\end{array}$ \\
\hline $\mathrm{RE}_{2} \mathrm{O}_{3}(\%)$ & 2.0 & 9.0 & 3.5 & 1.5 & 0.36 & 8.0 & 4.0 \\
\hline $\mathrm{La}$ & 2,171 & 19,778 & 7,454 & 2,089 & 294 & 15,959 & 8,708 \\
\hline $\mathrm{Ce}$ & 7,166 & 38,510 & 14,154 & 5,755 & 1,136 & 33,257 & 16,887 \\
\hline $\operatorname{Pr}$ & 1,319 & 3,745 & 1,607 & 813 & 221 & 3,859 & 1,682 \\
\hline $\mathrm{Nd}$ & 5,061 & 10,785 & 4,951 & 3,265 & 1,000 & 11,172 & 4,650 \\
\hline $\mathrm{Sm}$ & 567 & 749 & 349 & 313 & 158 & 797 & 329 \\
\hline $\mathrm{Eu}$ & 67 & 104 & 58 & 50 & 30 & 201 & 35 \\
\hline Gd & 134 & 441 & 204 & 100 & 57 & 531 & 232 \\
\hline $\mathrm{Tb}$ & 17 & 77 & 30 & 13 & & 68 & 33 \\
\hline Dy & 50 & 150 & 86 & 12 & 24 & 197 & 132 \\
\hline Ho & & & & & & & 31 \\
\hline $\mathrm{Er}$ & 16 & & 28 & & 9 & 64 & 32 \\
\hline $\operatorname{Tm}$ & & & & & & & \\
\hline $\mathrm{Yb}$ & 16 & 72 & 28 & & 3 & & 67 \\
\hline $\mathrm{Lu}$ & & 72 & 28 & & & & 32 \\
\hline $\mathrm{Y}$ & 134 & 372 & 174 & 101 & 79 & 466 & 232 \\
\hline $\begin{array}{l}\sum \mathrm{La}-\mathrm{Eu} / \\
\sum \mathrm{Gd}-\mathrm{Lu}, \mathrm{Y}\end{array}$ & 44.55 & 62.22 & 49.43 & 54.36 & 16.51 & 49.20 & 40.82 \\
\hline$\delta \mathrm{Eu}$ & 0.57 & 0.56 & 0.67 & 0.74 & 0.86 & 0.97 & 0.40 \\
\hline \multirow[t]{2}{*}{ 試 料 数 } & 7 & 9 & 6 & 3 & 1 & 6 & 11 \\
\hline & $\begin{array}{l}\text { 曹閃石型 Nb- } \\
\mathrm{RE} \text {-鐟鉱石 }\end{array}$ & 苦 灰 岩 & 粗粒苦灰岩 & $\begin{array}{l}\text { 中-粗粒黒雲 } \\
\text { 母花崗岩 }\end{array}$ & $\mid$\begin{tabular}{l|} 
中-粗粒角閃 \\
石-黒雲母花 \\
崗岩
\end{tabular} & $\begin{array}{l}\text { 中-粗粒黒雲 } \\
\text { 母花宬岩 }\end{array}$ & $\begin{array}{l}\text { 細粒黒雲母 } \\
\text { 花崗岩 }\end{array}$ \\
\hline $\mathrm{RE}_{2} \mathrm{O}_{3}(\%)$ & 1.14 & 0.065 & 0.057 & 0.04 & 0.047 & 0.043 & 0.03 \\
\hline $\mathrm{La}$ & 1,798 & 123 & 84 & 73 & 82 & 95 & 50 \\
\hline $\mathrm{Ce}$ & 4,835 & 275 & 218 & 146 & 154 & 162 & 89 \\
\hline $\operatorname{Pr}$ & 566 & 27 & 29 & 14 & 19 & 17 & 13 \\
\hline $\mathrm{Nd}$ & 1,965 & 73 & 96 & 50 & 58 & 49 & 40 \\
\hline $\mathrm{Sm}$ & 148 & 9 & 15 & 10 & 12 & 7 & 8 \\
\hline $\mathrm{Eu}$ & 30 & 1 & 5 & 2 & 3 & 2 & 1 \\
\hline $\mathrm{Gd}$ & 89 & 6 & 10 & 8 & 11 & 7 & 8 \\
\hline $\mathrm{Tb}$ & & 2 & 1 & 1 & 2 & 2 & 1 \\
\hline Dy & 20 & 7 & 6 & 6 & 10 & $4 .^{5}$ & 7 \\
\hline Ho & & 1 & 2 & 1.5 & 2 &.$^{5}$ & 3 \\
\hline Er & & 1 & 2 & $2 .{ }^{5}$ & $4 .^{5}$ & 3 & 3.5 \\
\hline $\mathrm{Tm}$ & & & & & 1 & .5 & 1 \\
\hline $\mathrm{Yb}$ & & 4 & 3 & 2 & $4 .^{5}$ & 2 & 3 \\
\hline $\mathrm{Lu}$ & & 1 & & & 1 &.$^{5}$ & .5 \\
\hline $\mathrm{Y}$ & 50 & 21 & 17 & 24 & 34 & 17 & 28 \\
\hline $\begin{array}{l}\sum \mathrm{La}-\mathrm{Eu} / \\
\sum \mathrm{Gd}-\mathrm{Lu}, \mathrm{Y}\end{array}$ & 58.75 & 12.48 & 11.09 & 6.67 & 4.75 & 9.42 & 3.67 \\
\hline $\begin{array}{c}\delta \mathrm{Eu} \\
\text { 試 料 数 }\end{array}$ & 0.80 & 0.26 & 1.17 & 0.77 & 0.82 & 0.84 & 0.55 \\
\hline
\end{tabular}

注: $\mathrm{RE}_{2} \mathrm{O}_{3}$ は平均含有率。 $\mathrm{La} \sim \mathrm{Y}$ は $\mathrm{ppm}_{\text {。 }}$ 
第 6 表 白雲鄂博鉄鉣休の鉱体別平均品位

（陳国達 1982）

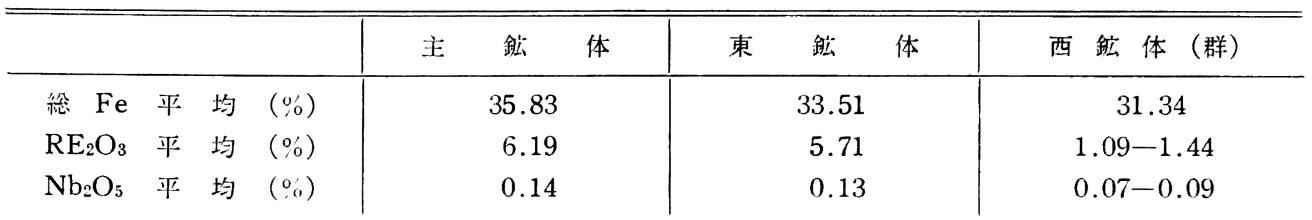

数值が挙げられている。古くは丁道衡 (1933) が 示した鉄鉱としての平均品位, $\mathrm{Fe} 67.40 \%, \mathrm{P}$ $0.066 \%, \mathrm{SiO}_{2} 12.27 \%$, 菌部竜一(1952)による主 要鉱体 I (今の主鉄鉱体) の平均品位, $\mathrm{Fe} 48.59$ $\%, \mathrm{SiO}_{2} 9.98 \%, \mathrm{P} 0.21 \%, \mathrm{~S} 0.07 \%$, 主要鉱 II (今の東鉄鉱体)の $\mathrm{Fe} 55.89 \%, \mathrm{SiO}_{2} 0.54 \%, \mathrm{P}$ $0.13 \%$, S $0.061 \%$ ，という数值がある。

本鉱床が Nb-RE- 鉄鉱床であることが確認さ れて以降に明らかにされた，鉱石の品位ないし鉱 床の平均品位およびそれに密接な関係のある数值 には，周振玲・李功元ら（1980）による，次に掲 げる第 4 表, 王凱怡（1981）による前掲の第 3 表, 表愉卓・王中㴊ら（1981）による第 5 表, 陳 国達（1982）による第6 表がある。

埋蔵量に関しては, 鉱床の発見者である丁道衡 （1933）が主鉱体の鉄鉱の鉱量を 3,200 万 , その 他の鉱体分を合せて鉄鉱合計 3,400 万 $\mathrm{t}$ ，螢石 3 万 $\mathrm{t}$ と算定し，菌部竜一（1952）が鉄鉱量6,021 万 $\mathrm{t}$, 門倉三能（1940）が鉄鉱量 1,500 万 $\mathrm{t}$ 以下, 熊丸 徹(1973)が同じく鉄鉱量15,000万 $\mathrm{t}$ とそれ ぞれ算定した。しかし最近まで中国は本鉱床の鉱 量の具体的な数值の発表をひかえ，1982年11月 8 一11日に開かれた杭州での第 1 回希有金属生産・ 利用国際会議の席上でやっと公表した。それは 中国金属学会副理事長の棌鴻儒（1983）の報告の 中で明らかにされたもので，それによると，本鉱 床の鉱量（おそらく探査鉱量）は鉄量にして 11.5 億 $\mathrm{t}$, 希土類元素量にして 3,500 万 $\mathrm{t}$, ニオブ量 にして78万 $\mathrm{t}$ である。さらに棌鴻儒は，本鉱床の 希土鉱中の $\mathrm{Eu}_{2} \mathrm{O}_{5}$ と $\mathrm{Sm}_{2} \mathrm{O}_{5}$ の含有率がアメリ カのマウンティンパス鉱床の場合よりも 2 倍以上 高いことを強調している。

\section{VIII. 成 因}

本鉱床の成因については諸説があり，まだ固ま
っていない。その説としては, 高温熱水交代説 （季旈英 1959）, 堆積変成熱水交代説（王中剛 李紹柄ほか 1973 , 中国科学院地質研究所 - 貴陽 地球化学研究所 1974), カーボナタイト説（周 振玲・李功元ほか 1980), 熱塧水沈殿被変成説 （曾久吾 1979 [国放資料]），堆積変成熱水重複 説（涂光嘖 1981）堆積一熱水交代（一接触交代） 説（陳国達 1982）, 海底火山成溢流カーボナタ イト説（白鸽 1967 [国内資料]，白鸽・袁忠信 1983）などがある。

この諸説の中で，多くの支持を得ているのが堆 積変成熱水交代説である。そして，この説に真向 から対立しているのがカーボナタイト説（マグマ カーボナタイト説ともよばれている) である。こ こでは，主にこの 2 説について概要を紹介する。

\section{1）堆䅪変成熱水交代説}

これは，原生代に浅海相の Fe と REに富んだ 珪酸質および珪酸アルミナ質砕屏岩と炭酸塩岩が 堆積し (堆積階段), それが弱い広域変成作用を 受け, 苦灰岩が再結晶するに伴って同岩中の RE とPがモナズ石として晶出し， Fe はアンケライ 卜, 菱鉄鉱, 赤鉄鉱, 磁鉄鉱などの形で晶出し (変成階段), この変成作用後に花崗岩が貫入して 苦灰岩との接触部に主としてマグネシア質スカル ンをつくり,そのスカルン帯に磁鉄鉱, 螢石, さ らに RE 鉱物として主に RE の珪酸塩鉱物, 寸 なわち褐策石, チェヴキナイト, 珪酸燐灰セリウ ム鉱などをもたらし（スカルン化段階），それに ひき続いて 熱水鉱液の 活動があって $\mathrm{Na}, \mathrm{F}, \mathrm{K}$, $\mathrm{P}, \mathrm{S}, \mathrm{Be}$ による側岩の選択交代現象を生じて RE の弗素炭酸塩鉱物やモナズ石・エシナイトなどを 生成した（熱水交代段階）とする説である。

王中剛・李紹柄ら（1973）がこの説を提起する に当ってその根拠としたのは，

（i）鉱床が卓状地と地向斜の 過途帯に 位置 
第 7 表 各地質生成体の同位体年代*上各鉱化段階の区分

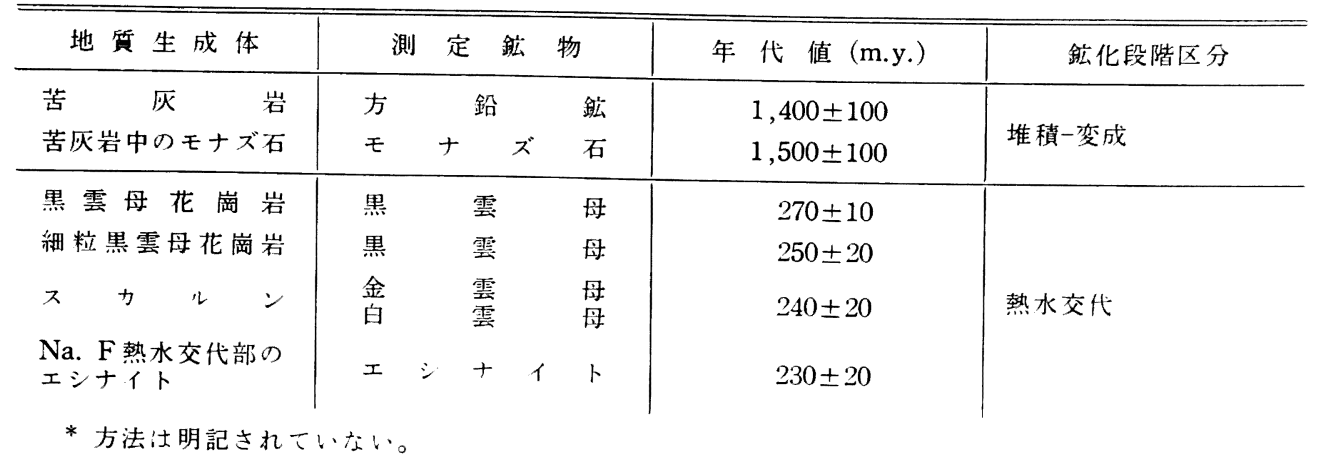

し，その卓状地は始生代の片麻岩類々花崗岩 バソリスで構成され, 希土類に富んだ花崗岩 ペグマタイトが広く分布すること，

（ii）鉱床の母岩が原生代の苦灰岩で，粘 板岩・珪岩・苦灰岩質珪岩などを挾有し, 呂 梁変動によって褶曲し, 隆起して東西性の構 造を形つくり，大小の鉄鉱体を胚胎するだけ でなく，苦灰岩自体が比較的 RE に富んで いること，

（iii）鉱石の組成が複雑で, 水平・垂直の 累带配列（化学成分も鉱石タイプも）がみら れること，

(iv) 花崗岩体と苦灰岩との接触部にスカ ルンが形成され，その中に鉱石鉱物がかなり

多量に含まれていること，

（v） とくに鉱石釷物（磁鉄鉱と赤鉄鉱）の酸 素同位体組成が鉱石のタイプによって明瞭に異な ること,

（vi）各地質生成体の同位体年代の測定が第 7 表に示す結果を得たこと，などである。

その後, 肖仲洋 (1975) が K-Ar 法によって追 試した結果は第 7 表の值とおおむね一致し, さら に姜傳武・張任祐ら（1982）は本鉱床区域の最古 の岩層（二道洼層群とした）とその上に不整合に のった白雲鄂博層群（鉱床の母岩である炭酸塩岩 を有する層群), 火成岩類, 鉱石鉱物と脈石鉱物 の K-Ar 法による同位体年代, $\mathrm{Sr}^{87} / \mathrm{Sr}^{86}$ 比, $\mathrm{Rb}-\mathrm{Sr}$ 法による同位体年代, 硫化物鉱物の $\delta \mathrm{S}^{34}$ および 炭酸塩鉱物の $\delta \mathrm{C}^{13}$ と $\delta 0^{18}$ の值の分布上の特徵, さらに炭酸塩鉱物の気液包有物のデクレピテーシ

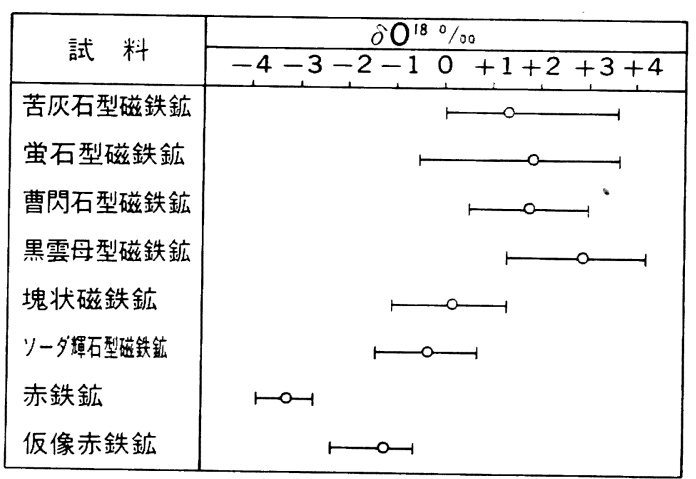

第 9 図バヤンオボ鉱床産磁鉄鉣および赤鉄鉱の $\delta 0^{18}$ の変化域(魏菊英・上官志冠 1983)

注：一型磁鉄鉣上は一型鉣石産磁鉄鈗の意味である。

ヨン温度值からアプローチして, 母岩である苦灰 岩は堆積岩であると結論づけ，鉱床の成因につい ては基本的に堆積変成熱水交代説を支持した。た だ, 姜傳武・張任祐らの表現は堆積変成熱水改造 鉱床となっていて，「交代」でなく「改造」一reconstruction 一と言いかえているが， $\mathrm{Na}$ 交代作 用に伴って大量の磁鉄鉱が生じたと述べているこ とからみても, とくに「改造」と言いかえる必要 はないと思われる。

加えて, 魏菊英・上官志冠 (1983) は磁鉄鉱と 赤鉄鉱の酸素同位体組成を求め, それを第 9 図に 示すように鉱石のタイプ別に解析し, 苦灰石型・ 螢石型・曹閃石型 - 黒雲母型の各磁鉄鉱鉣石を堆 積一変成作用の生成物で, 生成温度がおよそ 280 $330^{\circ} \mathrm{C}$ (局部的には変成温度 $400^{\circ} \mathrm{C}$ 前後), 塊状型 とソーダ輝石型の磁鉄鉱鉣石を苦灰石型鉣石など 


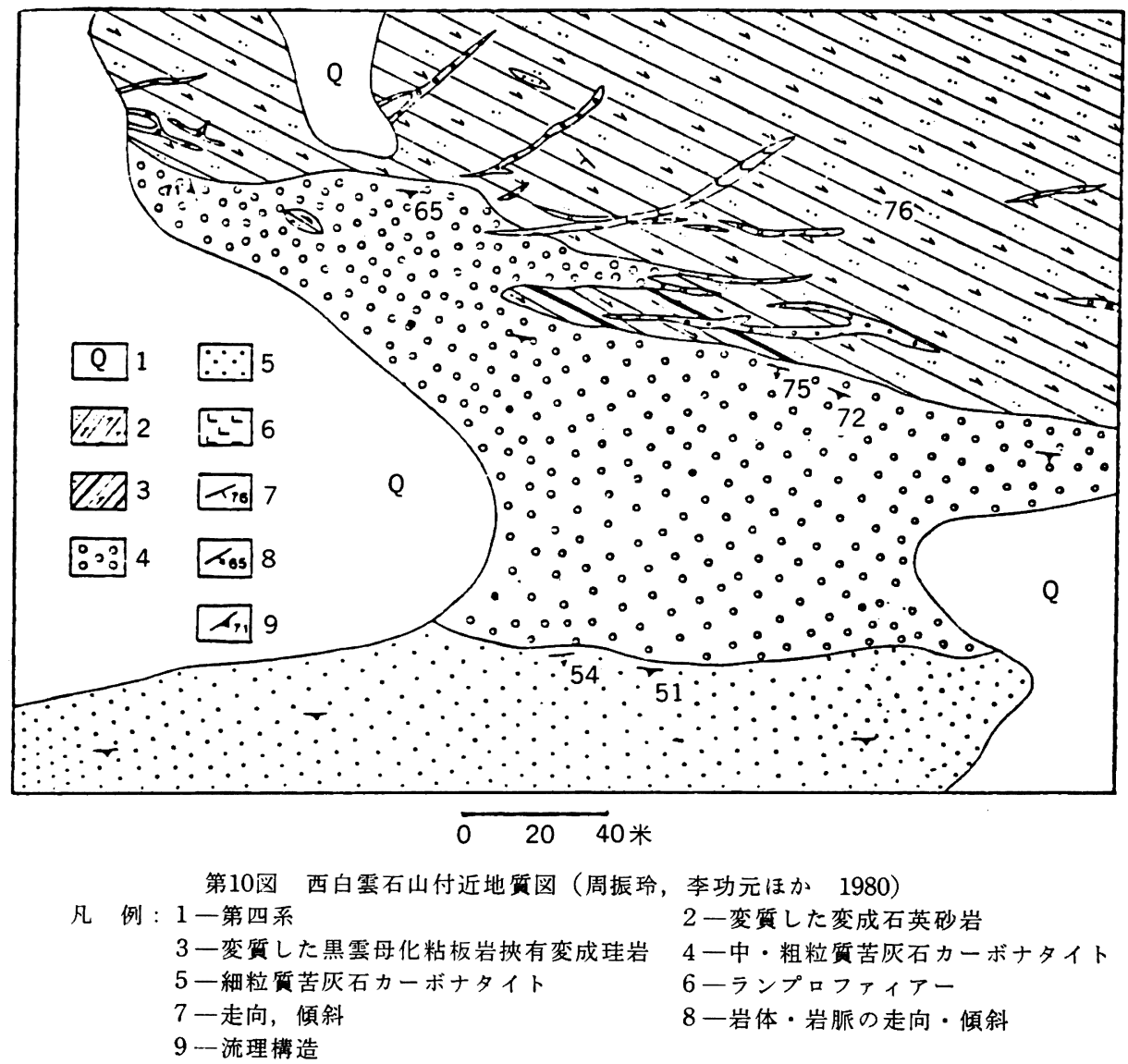

の熱水交代生成物で, 早期熱水作用の温度が $375^{\circ}$ $\mathrm{C}$ 前後, 後期熱水作用の温度がおよそ $240-250^{\circ} \mathrm{C}$ であったなどの結論をひきだして，堆積変成熱水 交代説を支持している。

\section{2) カーボナタイト説}

内蒙古地質局地質研究隊の周振玲と李功元およ び同局実験室の宋同雲と劉宇光 (1980) が提唱し た本説は，本鉱床を原生代の浅海相砂岩・頁岩 · 石灰岩層中に貫入した原生代末期のカーボナタイ ト中に鉱石鉱物が濃集したものと主張し, 当該力 一ボナタイトを南北 2 帯に分け, 北側の当該岩帯 の延長を $18 \mathrm{~km}$, 平均の幅を $400 \mathrm{~m}$ 余としている。 この説の根拠とされているのは, 次のような現 象である。

（i）原生代末期に超塩基性岩，はんれい岩, ア
ルカリ輝緑岩, アルカリ閃長岩が貫入し, その貫 入時期と「カーボナタイト」の生成時期がほぼ一 致し，ともに構造規制を受けて分布し，層準規制 を受けていないこと，

（ii）当該岩体は原生代堆積層を $15-30^{\circ}$ の角度 で切っていて(第10図), その内接触帯 (endocontact）に石英砂岩・粘板岩・閃緑岩などの捕獲岩 を有し, 縁部に幅 $5-10 \mathrm{~cm}$ の急冷周縁相がみら れること,

（iii） 当該岩石の鉱物組合せ（初生鉱物一苦灰 石・アンケライトを主とし, 方解石・燐灰石・磁 鉄鉱・コロンバイト・金雲母・モナズ石・バスト ネサイト・ジルコンなど；交代変質鉱物一その 中では螢石・曹閃石・ソーダ輝石・重晶石・黒雲 母・赤鉄鉱・モナズ石・バストネサイト・コージ 
ライト・パイロクロア・エシナイトを主とし，燐 灰石・黄銅鉱・黄鉄鉱・方鉛鉱・閃亜鉛鉱・菱鉄 鉱・微斜長石・石英 ; 表成鉱物一褐鉄鉱・赤鉄 鉱・ランタナイト・カオリンなど), 化学組成 (第 4 表参照)，希土類元素の配分（第12図）の諸特徽 および岩石組織・構造が内外のカーボナタイトの 場合によく似ていること，

（iv）当該岩石の自交代作用が発達していて, その作用が希土類と希少金属の濃集を促進してい ること，

（v）当該岩体の側岩が程度はさまざまである が, 変質され, その変質は同岩体から遠ざかるに したがって弱まり, 側岩の岩種が異なり, 変質過 程の特徴が異なっていても, 成分の添加と溶脱の 成分は同じで, 添加成分はカーボナタイトに特有 のものであること，などである。

そして周振玲・李功元らは，本鉱床をカーボナ タイトマグマの分化過程の産物とし，とくに鉄鉱 体を熔離型と説明している。

なお, 白鸽・袁忠信の海底火山成溢流カーボナ タイト説は鉱床を胚胎した炭酸塩岩がカーボナタ イトマグマの海底で海水と反応しながら沈殿した 苦灰岩であるとし，その活動の末期に貫入カーボ ナタイトが生成したと説明するものである。した がって, カーボナタイト岩脈の規模は上記カーボ ナタイト説の場合よりもはるかに小さく, 鉱石生 成過程の説明もかなり異なるだけでなく, 非常に 詳しく, かつ論拠も多様であるが, 紹介には多く の紙数を要するので割愛する。

それに代って，孟慶潤（1982）のバヤンオボ鉱 㦿の母岩の堆積岩説はぜひとも紹介しておきた い。彼の主張は周振玲・李功元らのカーボナタイ 卜説への反論である。

3）母岩堆積岩説

孟慶潤が母岩である炭酸塩岩をカーボナタイト でなく,堆積成苦灰岩であると結論うけた根拠は，

(i ) 当該炭酸塩岩 (苦灰岩) を伴な5白雲鄂 博層群の分布は内蒙古一帯に及び，きわめて広大 であり，その中で苦灰岩は同一層位を占めること，

(ii) 当該苦灰岩の層理融々下盤のメ夕長石一 石英砂岩層との接触面が20-70 で交わる部分 (第 11図).は前者の貫入接触面でなく, 断層による接

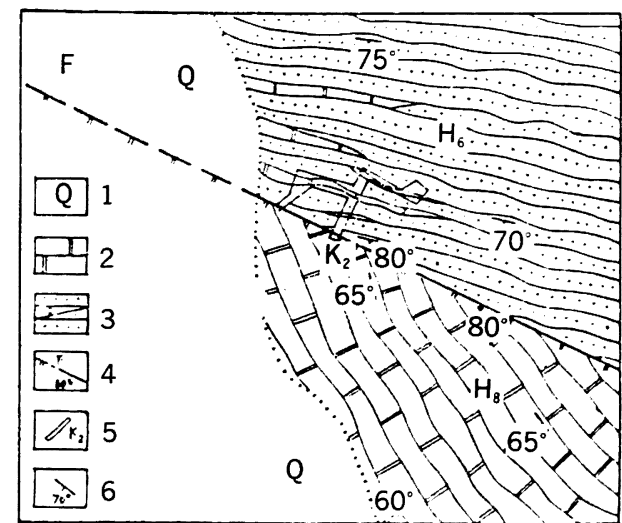

第11図 バヤンオボ鉣床主鉣体 $\mathrm{K}_{2}$ トレンチ付近 の地質図（孟序潤 1982）

凡 例 : 1一第四采 $2-\mathrm{H}_{8}$ 層苦灰岩 $3-\mathrm{H}_{6}$ 層又夕長石・石英砂岩, 苦灰岩を挾有 4 一逆断層 5 -トレンチ $\mathrm{K}_{2}$ 6 一走向・傾斜

触面で, 接触面付近での岩石のマイロナイト化現 象が明瞭なこと，

（iii）当該苦灰岩と白雲鄂博層群 $\mathrm{H}_{8}$ 層構成岩 層（第 2 表参照）との互層が多くみられること，

（iv） 西鉱体群 12 号鉱体の上盤と下盤の苦灰岩 などから藍緑藻類, 菌藻類, 胞子などの化石が産 出し，陸源砕屑物も随伴されていること，

（v） 変成作用の非常に弱い苦灰岩中には，ア ンケライト，苦灰石，磁鉄鉱などの定向配列に伴 なった筋状, 縞状構造がはっきり残り, 層理を形 うくっていること，

（vi）苦灰岩中に有機炭素が平均 $0.061 \%$ も含 まれていること， などである。そして彼はその苦灰岩の堆積環境と $\mathrm{Fe}$ など造鉱物質の起源について，

（i ）鉱床区域の東・西・北の三方の 3 組の古 断裂によって形成された地溝構造が $\mathrm{H}_{8}$ 含鉱岩層 の堆積を規制し，とくに北の寛溝断層の生成と成 長がその北側と南側の堆積環境を違ったものにし て, この南側の断層陥没盈地の生成と堆積環境の 変化が堆積物の内容を規制する主な要素となっ た,

（ii）含鉱苦灰岩を生成した水媒体は浅い水体 で, その水の運動力学的条件は潮汐作用を主とし, 
波浪作用の微弱な低エネルギーの閉鎖ないし半封 鎖・蒸発型の潟湖性堆積環境であった,

（iii）含鉄岩層が形成された地球化学的環境は 環元一アルカリ媒体環境であった，

（iv） 造鉱物質の来源は, $\mathrm{Fe}, \mathrm{Be}, \mathrm{RE}$ が陸源 であることを除けげ，すべて深部地層からの塩水 である, と結論ゔけている。

\section{IX.おわりに}

以上が世界一だろうといわれる RE-Nb- 鉄鉱 床についての紹介である。この紹介で示したよう に，本鉱床の成因や鉱床をとりまく地質に関して まだ定説がなく，とくに成因論は多様である。現 場を知らず，標本も見たことがないので，「君は どう思うか」とたずねられても断定的な回答は出 せない。某社では，専門家を現地に派遣されたと 聞くが, どうやら調査結果は部外秘のようである。 バヤンオボ鉱床は希土類の資源としてもニオブ の資源としても, 現在その一部の資源は世界で 余っているとはいえ，やはり注目すべき鉱床であ る。今後の調査研究のおもむくところを筆者は見 まもりたい。アメリカなど中国以外での本鉱床に 関する報告はいずれも原典を中国の専門家の論文 や講演に求め, とくに新味があるものはない。

蚌愉卓・王中剛ら（1981）によると，バヤンオ ボ RE-Nb-鉄鉱床と同種・同タイプの鉱床が少な くとも 4 山（松政, 迎納廠, 筆架山, 桃花拉山） 存在している。この 4 山に関して知ることができ るなら，バヤンオボ鉱床に関する鉱床地質学的認 識はさらに深まるに違いない。それを期待しなが ら、この稿を終る。

\section{注}

1) ソ連人専門家は本鉱床を高温熱水性鉣床 と結論ゔけた（陳国達 1982）。

2) 本釷床の堆積成因説は謝家栄が最初に提 起し，当時支持されなかった（陳国達 1982)。謝家栄がどのような形で，いっ 堆樌説を発表したのかは不明である。

3）白鸽・袁忠信（1983）はカーボナタイト マグマの海底での活動を主張している。

4）上記の炭酸塩岩の堆積岩説とマグマ岩説 のそれぞれの根拠については，「鉱床の 成因」の項で紹介する。
5）王中剛・李紹柄ほか（1973）の地質図（第 2 図）上では $\mathrm{H}_{3}$ と表現してある。

6）カーボナタイト説をとる人はこれを 「流理」としている。

\section{文献 (引用順)}

丁道衡(1933)：綏遠白雲鄂博鉄鉱報告. 地質 粢報，第23号，53-58頁.

菌部童一(1952)：内蒙古烏闌察布盟バイン・ ボクト鉄鉱床調查報告. 東要地犋鉱産誌, 華北 - 火鉱- I i-1, p. 1-6.

李矮英 (1959)：白雲鄂博鉄䂜地啠与勘探：地 質出版社, 北京.

王中剛・李紹柄・蘇蜸沢 (1973)：沈積変澌一 熟液交代型希土, 鉄砿床的成因特徽. 地球 化学, 第 1 期, 5-11頁.

中国科学院地啠研究所 - 貴陽地球化学研究所 （1974）：内蒙古白雲鄂博砿床的物質成分地 球化学及成砿規律的研究. 北京.

周振玲・李功元・朱同雲・劉宇光(1980)：内 蒙古白雲鄂博白雲石炭酸岩的地梊特徽及其 成因探討. 地澌論評, 第 26 巻, 第 1 期, 35 -42 頁.

涂光嘖, Tu Guangzhi (1981): On the mineral deposits of Bayan Obo and Shilu. Scientia Sinica, vol. XXIV, No. 2, p. 228-236.

孟慶潤(1982)：論白雲鄂博鉄砿含鉣囲岩一白 雲岩的沈積成因及其沈皘環境分析. 地僙論 評, 第28巻, 第 5 期, 481-489頁.

王凱怡 (1981)：白雲鄂博鉄希土砿床中希土元 素的分配特点. 地犋科学, 第 4 期, 360367 頁.

陳国達 (1982)：多因複成砿床并従地殸演化規 律看其形成機理. 大地構造与成矿学, 第 6 巻, 第 1 期, 33-55頁.

姜傳武・張任袏・潘均・朱洪山・李平 (1982): 白雲鄂博砿床同位素地啠研究. 地質科研成 果選集, 第 1 集, 270-276頁.

肖仲洋 (1975)：全国同位素地質会議文集，22 -28 頁：地啠出版社，北京.

王凯怡・楊瑞英(1983)：白雲鄂博輝長岩的希 土含量. 地犋科学, 第 2 期, 195-198頁.

王凯怡 (1981)：白雲鄂博鉄希土砿床中希土元 素的分配特点. 地啠科学，第 4 期，360-367 頁.

熊丸 徽 (1973)：中国の鉄鋼原料. 铁鋼新閚 社, 東京, 70-71頁.

装愉卓・王中剛・趙振華 (1981)：試諭希士鉄 建造. 地球化学, 第 3 期, 220-230面. 門倉三能(1940)：北支鉄鉱・硫黄釷资源．丸 
善, 東京, 199-203頁.

白鸽・袁忠信 (1983)：白雲碞博矿休成因分析. 中国地質科学院砿床地質研究所所刊，第 4 号, 1-15頁。

張培善 - 陶克捷 (1981)：新鉱物中華鈰鉱 $\mathrm{Ba}_{2}$ $\mathrm{Ce}\left(\mathrm{CO}_{3}\right)_{3} \mathrm{~F}$. 地倎科学, 第 2 期, 195-196 頁.

王守信・王凱怡・喬広生・張鳳秋 (1981)：白 雲鄂博矿床中易解石的釹同位素. 地澌科学, 第 2 期，197-196頁.
張培善・陶克捷 (1983)：氟湠鈰鋇硡 (Cebaite) 的新資料. 地啠科学, 第 4 期, 409-413頁. 魏菊英・上官志冠(1983)：内蒙古白雲鄂博鉄 䂯床中磁鉄砿和赤鉄砿的氧同位素組成. 地 質科学, 第 3 期, 217-223頁.

孫鴻儒 (1983)：中国希有金属資源和生産概况. 希有金属，第 2 巻，第 1 号，1-4頁。

(1985年 1 月23日受理) 